\title{
PESSOA ON CAMÕES' OS LUSÍADAS: METER, GRAMMAR AND RHYTHM
}

\section{PESSOA SOBRE OS LUSÍADAS DE CAMÕES: METRO, GRAMÁTICA Y RITMO}

\author{
JAVIER ARIAS NAVARro \\ Centro de Linguística da Universidade de Lisboa \\ Escuela de Lógica, Lingüística y Artes del Lenguaje de Asturias \\ PATRICIO FERRARI \\ Centro de Estudos Comparatistas da Faculdade de Letras da \\ Universidade de Lisboa \\ Department of English (Stockholms Universitet)
}

\begin{abstract}
The present paper focuses on the philological reconstruction and account of Fernando Pessoa's scansion of one verse from Os Lusiadas, as presented in some unpublished draft notes for his projected Treaty of Prosody and Poetics. To begin with, Pessoa's analysis of rhythmic pauses is introduced. Secondly, Robert Bridges' «stressunits» are presented, which constituted the main inspiration for Pessoa's scansion. Furthermore, a brief interpretation in terms of the generative theory of meter is put forward, which underscores the analogies and differences between the two linguistic traditions Pessoa worked with. Last but not least, the implications of Pessoa's scansion for phrasing in Camões' verse are also taken into account. A critical transcription of Pessoa's analysis on Camões is included in the Annex.
\end{abstract}


Keywords: Portuguese Decasyllable, Generative Metrics Luís Vaz de Camões, Fernando Pessoa, Robert Bridges, Rhythmical Pauses, Os Lusíadas

Resumen: El presente texto se centra en la reconstrucción filológica y análisis de la escansión que Fernando Pessoa efectuara de uno de los versos de Os Lusíadas en las inéditas notas preliminares a su proyectado Tratado de Prosodia y Poética. En primer lugar, se presenta el tratamiento de las pausas rítmicas por parte de Pessoa. En segunda instancia, se introducen las «unidades rítmicas» (stress units) de Robert Bridges, que constituyeron la principal inspiración para el pensamiento pessoano. Además, se adelanta una breve interpretación en términos de la teoría generativa del metro, subrayando las analogías y diferencias entre las dos tradiciones lingüísticas en las que trabajaba Pessoa. Por último, se estudian las consecuencias que del análisis de la escansión pessoana se derivan para el fraseo del verso de Camões. Como anexo se incluye una transcripción crítica de los análisis de Camões de Pessoa.

Palabras clave: Decasílabo Portugués, Métrica Generativa, Luís Vaz de Camões, Fernando Pessoa, Robert Bridges, Pausas Rítmicas, Os Lusíadas. 


\section{Introduction}

7 he British education that Fernando Pessoa received in Durban (1896-1905) ${ }^{1}$ allowed him to become acquainted with the rules of two renowned, yet quiet different, poetical traditions. It was through the voice of Virgil
and Horace, as well as that of Milton and Shakespeare, among others, that the young Portuguese first came in contact with the meter and rhythm of Latin and English poetry. In fact, in some of the books Pessoa brought back to Lisbon, and that make up a small fraction of his 1311-title collection ${ }^{2}$, we find annotations in the margins and in-between verses that unveil a formal study of versecraft. His archive is not less profusely rich in that respect: manuscripts dating from the formative years testify the importance that the then aspiring-poet reserved to both poetic diction and different technical aspects of poetry.

The fact that Pessoa's juvenile English poems were mostly built upon the metrical models of certain poets he had read while in South African soil comes not as a surprise to us, particularly when we find that some of his initial Portuguese compositions, back in 1902, were moulded after the first Portuguese poets he had encountered. ${ }^{3}$ Be this as it may, Pessoa's early relationship with poetry was not only cultivated through the role of the writing-reader, but also within that of the translator -this latter

${ }^{1}$ Fernando Pessoa (1888-1935) lived in Durban, South Africa, from February 1896 to August 1905. In August 1901 he returned to Portugal where he remained until September of the following year, embarking once again for Durban. In December 1904 he completed his studies at Durban High School (Form VI).

${ }^{2}$ For Pessoa's Private Library see Pizarro, Ferrari and Cardiello (2010). The Collection has been digitally available since October 2010 at http://casafernandopessoa.cmlisboa.pt/bdigital/index/index.htm

${ }^{3}$ See, for instance, Pessoa's poem «Avé Maria» (dated 7 April 1902) after Francisco Palha's poem, also with the same title. 
practice amounting to one that both fuelled and fanned him and which we should neither diminish nor overlook in the overall comprehension of his poetics. Thus, before coming to grips with the way Fernando Pessoa -years later-scanned and commented one line of verse by Camões, a brief preliminary account becomes necessary.

\section{Pessoa's Origins as a Poet between Metrical Traditions}

It was as a translator that Pessoa first found himself between two prosodic traditions, the Latin and the English. This we find in a loose bi-folio of an early notebook:

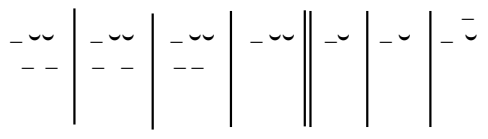

Pale death | now knocks | with foot | listless at $\|$ doors of $\mid$ rich and wretched

Detail $\left(27^{9} D^{2}-26 a^{v} \text { and } 26^{v}\right)^{4}$

In archiloquian verse ${ }^{5}$, just like the original, the transcription above is a translation of lines 13-14 from Horace's famous Ode I, IV: «Pallida mors aequo pulsat pede pauperum tabernas $/ \mid$ Regumque turres. [...]» (HoRACE, 1909: 14). ${ }^{6}$ The English rendering was done by filling long positions with stressed monosyllabic words, while making articles, prepositions and unstressed syllables fall in the short metrical positions. ${ }^{7}$ Curiously enough, it is in the same sheet that we read the following note:

${ }^{4}$ Unless the document has been critically published quotes will be directly from Pessoa's archive (Biblioteca Nacional de Portugal / Espólio 3) [National Library of Portugal / Archive 3]. In the former case the quote will be given without the respective call number. When a text has been published outside the critical edition, we will provide the call number, as well as the reference of the given publication. Following the critical edition, Pessoa's original spelling will be maintained.

${ }^{5}$ A metrical line consisting of seven feet, the first 4 being most commonly dactyls (or, alternatively, spondees), and the last three being trochees (the seventh foot may also be a spondee).

${ }^{6}$ These notes precede Pessoa's purchase of this book, which is also part of his private library.

${ }^{7}$ The only word that does not abide by this scheme is the preposition «with,» which is assigned to a long position. 
Charles Rob[er]t Anon ${ }^{8}$

Adaptation of Metre of Horace Odes I. IV.

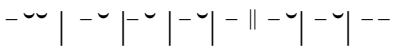

Detail $\left(27^{9} \mathrm{D}^{2}-26^{v}\right)$

The adapted metrical model headed with Charles Robert Anon's signature conserves the number of metrical positions but alters the number of feet preceding the caesura. ${ }^{9}$ Now, determining whether or not Anon's intention was -as Sir Philip Sidney, Alfred Tennyson and many others in the English tradition had attempted before him- to bring Latin rules into English verse goes beyond the scope of the present paper ( $c f$. ATTRIDGE, 1974). Nonetheless, one more thing should be borne in mind before we set to analyse Pessoa's prosodic notes on Camões: between 1904 and 1905, that is, a year or so prior to his final return to Lisbon, Fernando Pessoa came across the work of the English poet and prosodist Robert Bridges, Milton's Prosody, a book which included William Johnson Stone's Classical Metres in English Verse $(1901)^{10}$ and that distanced itself from the canonical scansions applied to Milton's poetry. In one of the latter's pages we find the ensuing markings and marginal annotation:

${ }^{8}$ Charles Robert Anon is the first pre-heteronym in Pessoa's literary system to attain particular relevance. Between 1904 and 1906 he was made owner of at least three books and was attributed, among others, both poetical and philosophical prose writings. Pessoan scholars have tacitly agreed that the literary personalities preceding the heteronymic eruption (i.e., early March 1914) are to be called preheteronyms. This terminology and its limitations will not be discussed here. $C f$. PizARro (2012). For a description of Charles Robert Anon as well as some texts attributed to this literary figure, see Eu Sou Uma Antologia (2013: 139-156).

9 While in the Horacian model there may be 10 long syllables and 5 short ones, in Anon's model we find 9 long syllables and 7 short ones. The two additional short syllables in Anon's model amount to 1 long one in Horace's model. Thus, the number of metrical positions is preserved.

${ }^{10}$ For a short list of books Pessoa brought from Durban, see Severino (1983: 297- 00). With regard to Robert Bridges' work, see Young (1914). 


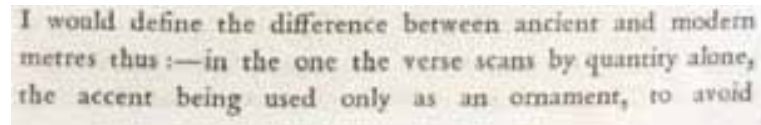

$\mathrm{N}[$ ota] $\mathrm{B}[\mathrm{ene}]$

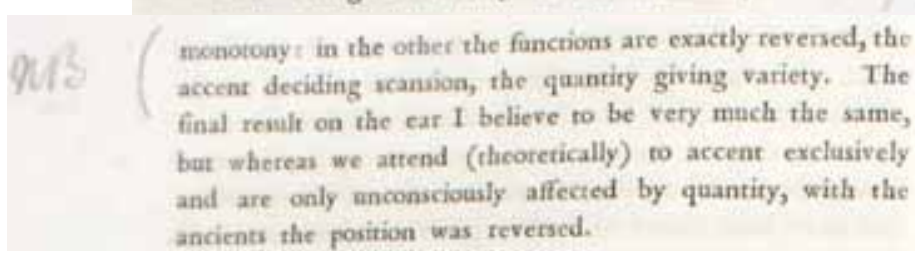

William Johnson Stone. Classical Metres in English Verse. Oxford: Henry Forwde, 1901. Detail of pages 117-118. (Fernando Pessoa House, 8-64).

Dating from $c$. 1909, the markings and other marginalia, particularly the scansions throughout Milton's Prosody, shed light on one of Pessoa's intellectual interests at the time, that branch of literary studies that has come to be known as comparative metrics ( $c f$. FowLER, 1977 and DUFFELl, 2008).

The «Tratado de Prosodia e de Poetica» (122-16r; Ferrari, 2012: 351-52), a follow-up to «Do Rhythmo» (PessoA, 2006: I, 37) and a far more ambitious project itself, likely began between 1909/1910, developed from Pessoa's analyses of Portuguese verse through the combination of two other different prosodic systems, the Latin and the English one, respectively. ${ }^{11}$ It was probably for his Treaty that the notes on Camões' verse were written. Never published by Pessoa, and perhaps still a rough draft, these notes seem to cover (at least partly) the material to be discussed in one of the main sections introduced in the main extant sketch of the Treaty: «Das pausas no verso» (122-16r; FERRARI, 2012: 351-52).

Now, there are three main features from Pessoa's project that have led us to choose this particular document for our analysis: (1) it contains the scansion and comments of one of the most represented poet in the Treaty, namely Luís de Camões; (2) it stems from Pessoa's readings of a British prosodist who might

${ }^{11}$ Before mid-November 1908 he writes a little more than 30 poems in Portuguese. Between mid-November and the end of the year he composes around 15. From then on his production in Portuguese will soar. 
be considered (at least in a broad sense) a pioneer or even a precursor of generative metrics (an approach to the study of meter which represents today one of the most productive schools of thought and analysis in metrics); (3) it provides us with empirical evidence, as shown in the Portuguese language, of the tight interplay between metrical structure and prosodic constituency, most notoriously reflected in phrasing.

The focus of this paper is the philological reconstruction and account of Pessoa's main source text, as expressed by his Treaty. Once such a connection becomes evident in all respects, a brief interpretation in terms of the generative theory of meter will be presented. ${ }^{12}$

This paper is organized as follows: (1) introduction to Fernando Pessoa's analysis of pauses through his scansion of one of Camões' verses from Os Lusiadas; (2) presentation of Bridges' «stress-units,» Pessoa's borrowings and the applications on the scansion in question; (3) formulation of the basic principles underlying the comparison of feet between two of the different linguistic traditions Pessoa worked with, considered at the light of generative metrics; (4) implications for phrasing on Pessoa's scansion of Camões' verse. At the end of the paper, following the concluding section and before the bibliography, the reader will find a critical transcription of the manuscript bearing one of Pessoa's rhythmical analysis on Camões.

\section{Pessoa on Camões' Rhythmical Pauses}

The fourth section of the Treaty deals with the types of pause in verse, which Pessoa discussed on the same loose sheet where he sketched the outline for his Tratado. In fact, it is one of these types of pauses that will become the focus of his own analysis of Camões' verse: $\overline{12}$ For the application of generative metrics on Pessoa's corpus, see Ferrari (2011 and
2012). 
Ha 3 especies de pausa em verso

(1) a pausa depois das palavras, muito pequena

(1) a pausa da cesura.

(3) a pausa grammatical.

(2) a pausa no fim do verso.

(1) determinado pelo rhythmo

(3) [determinado] pelo verso, claro está

(2) [determinado] pelo sentido.

$\left(122-16^{\text {r }} \text { Ferrari, 2012: 351-352) }\right)^{13}$

Three types of pauses are identified, that is, the pause of the caesura, the grammatical pause and the one that occurs at the end of the verse. It should be noticed that for the first type of pause Pessoa had initially written the following: «(1) a pausa depois das palavras, muito pequena.» Now, this pause (which includes the one of the caesura) is determined "pelo rhythmo». In his analysis of Camões' verse (145-36; for full critical see Annex) Pessoa illustrates the first type of pause in the following manner:

\section{Albuquerque |terribil, | Castro forte}

This scansion is twofold: (1) division of pauses; (2) nature of syllables. Regarding the latter, Pessoa's scansion respects the Portuguese heroic decasyllable model, which requires a stressed syllable on the $6^{\text {th }}$ and the $10^{\text {th }}$ positions, having the possibility of secondary accents on the $8^{\text {th }}$ and on one of the first four metrical

${ }_{13}$ Pessoa's «Tratado de Prosodia e Poetica» has been partially transcribed and discussed in Ferrari's dissertation (2012), which constitutes, among other matters regarding Pessoa's metrics, a new interpretation of the materials first transcribed and presented by Lemos (1993).

${ }^{14}$ Os Lusíadas (chant I, stanza 14, line 7). 
positions ( $c f$. CUNHA and CINTRA, 1984: 683) ${ }^{15}$. Nothing here then seems to deviate from the normal pattern. Only when we look at the insertion of pauses is it that questions may arise. Whereas the mark after «terribil,» stands for the caesura ${ }^{16}$ and does not cause any misunderstanding, the division between «Albuquerque» and «terribil» or the absence of a pause division between «Castro» and «forte» call for elucidation. Pessoa justifies his procedure thus: «as pausas rhythmicas dependem só da rhythmica» $\left(14^{5}\right.$ $36^{r}$ ). This explanation is by no means satisfactory, for, besides its redundancy, it does not reveal anything about the methodology. But let us move on for a moment. In the same document Pessoa provides another scansion of the same verse, this time adding a definite article in the first foot:

Albuquerqu' o|terribil| Castro forte.

Upon making an artificial line, Pessoa tells us that in order to be heard, yet without getting inadequately accentuated («sem o accentuar indevidamente»), the inserted article $o$ becomes detached from its host («terribil») -thus rhythmically falling into the last metrical syllable of the first foot. In other words, although grammatically belonging to the second foot -for it is

${ }^{15}$ Carvalho (1981b: 32), in turn, considers the stress on the 6 th and the 10th syllable to be the only defining and required features of the heroic modality of the Portuguese decasyllable.

${ }^{16}$ We are well aware of the fact that postulating caesura for the Portuguese decasyllable (or for some of its other Romance equivalents: thus, the famous initial line from Garcilaso de la Vega's Sonnet XXIII «En tanto que de rosa y azucena» would be ill-formed if caesura were assumed as mandatory in the Castilian hendecasyllable by the theory) is all but uncontroversial. However, by doing so in this particular case, we remain faithful to Pessoa's metrical thoughts leading to his scansion of Camoes's verse. That alone already justifies our approach and makes it legitimate, since the basic purpose of this paper is to achieve a reasonable understanding of the metrical analyses deployed on Camoes's line by a highly conscious poet like Pessoa, not to put forward a general pattern for all decasyllables in Portuguese. A thorough analysis of the history and structure of the decasyllable (or hendecasyllable, depending on the tradition) in West-Romance languages would be a topic for a future study. 
a proclitic of the noun «terribil»- its metrical place comes to be determined by an overriding rhythmical law. But what particular law does Pessoa have in mind? We clearly see that each division created by a pause insertion has only one accented syllable and that in terms of the nature of syllables -even with the addition of the definite article- the first and the third divisions are alike. One possible explanation for this ternary pause-division could go as follows: according to the Portuguese heroic decasyllable model, as stated before, there may be secondary accents (acentuações secundárias) falling on one of the first four syllables, as well as on the $8^{\text {th }}$. Accordingly, Pessoa sets one division per accented syllable. But why should he scan the $3^{\text {rd }}$ syllable as accented and disregard the $8^{\text {th }}$ ? Whatever the answer, one thing is clear: Pessoa's pause-division setting is not independent from his scansion of syllables.

In Pessoa's archive we find another manuscript, also likely to have been undertaken for the Tratado, which is contemporary ${ }^{17}$ of the one presented above. In this other document we find a list of rhythmical feet («pés rhythmicos») - some of them illustrated by parts of other verses taken from Camões' epic poem. Even before analysing these rhythmical feet more closely, a glimpse at one of the statements written there may disclose the nature of their construction: "[n]enhum pé rhy[tmi]co, a não ser o bisyllabo, pode começar por uma syllaba rhythmicamente accentuada. /ou isto é so em Portuguez/» $\left(14^{5}-37^{\mathrm{v}}\right)$. Pessoa is not so sure about the last part of his statement («ou isto é so em Portuguez») and leaves a sign of uncertainty ${ }^{18}$. But the very fact that he wonders whether this be true in Portuguese allows for the following hypothesis: in laying out his laws, Pessoa seems to be working with more than one prosodic system.

\section{From Bridges' "stress-units» to Pessoa's «pés rhythmicos»}

The reading of Bridges' work on Milton's prosody, particularly of the last appendix, «[o]n the rules of the common

${ }^{17}$ Both manuscripts were written with the same ink and on the same type of paper ( $c f$. $14^{5}-35$ and 37 ).

${ }^{18}$ One of Pessoa's ways of showing doubt is putting a word and/or set of words in brackets. 
lighter stress-rhythms, and the English accentual hexameter» (1901: 88-112) ${ }^{19}$, was the source for Pessoa's «pés rhythmicos,» as well as for some of his more technical reflections on rhythm for the Tratado:

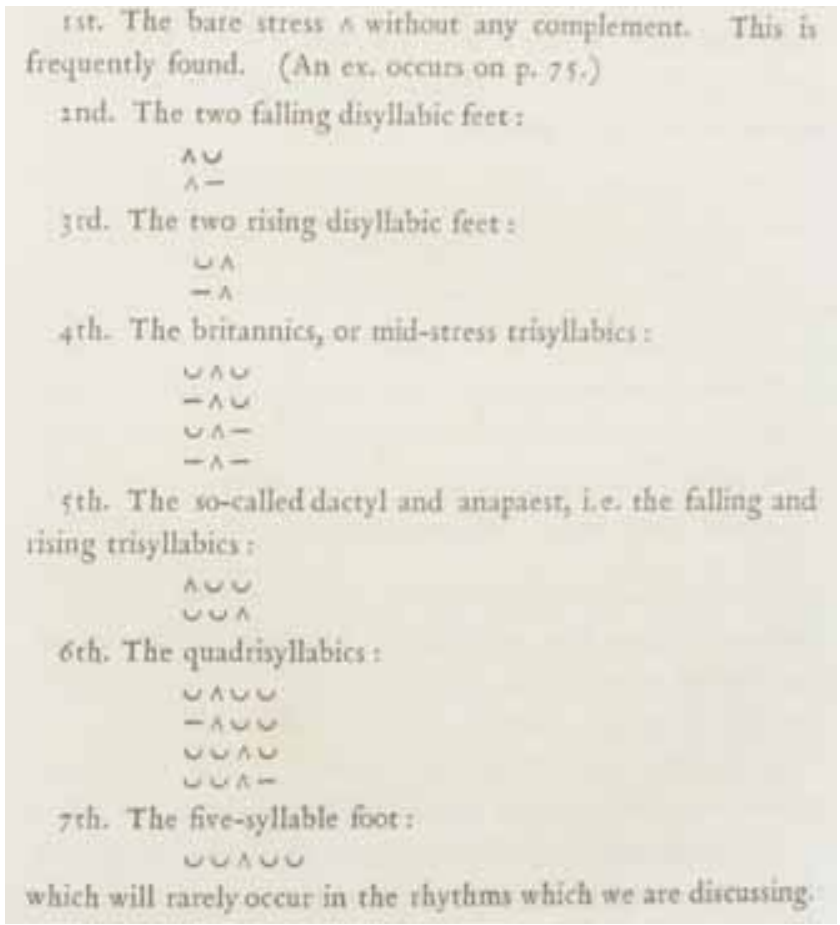

Detail. Milton's Prosody. Oxford: Henry Frowde, 1901, p. 97. (Fernando Pessoa House, 8-64).

${ }^{19}$ Bridges' first edition originally came out in 1893 . This section was added in the 1901 edition, that is, the one found in Pessoa's Personal Library. 


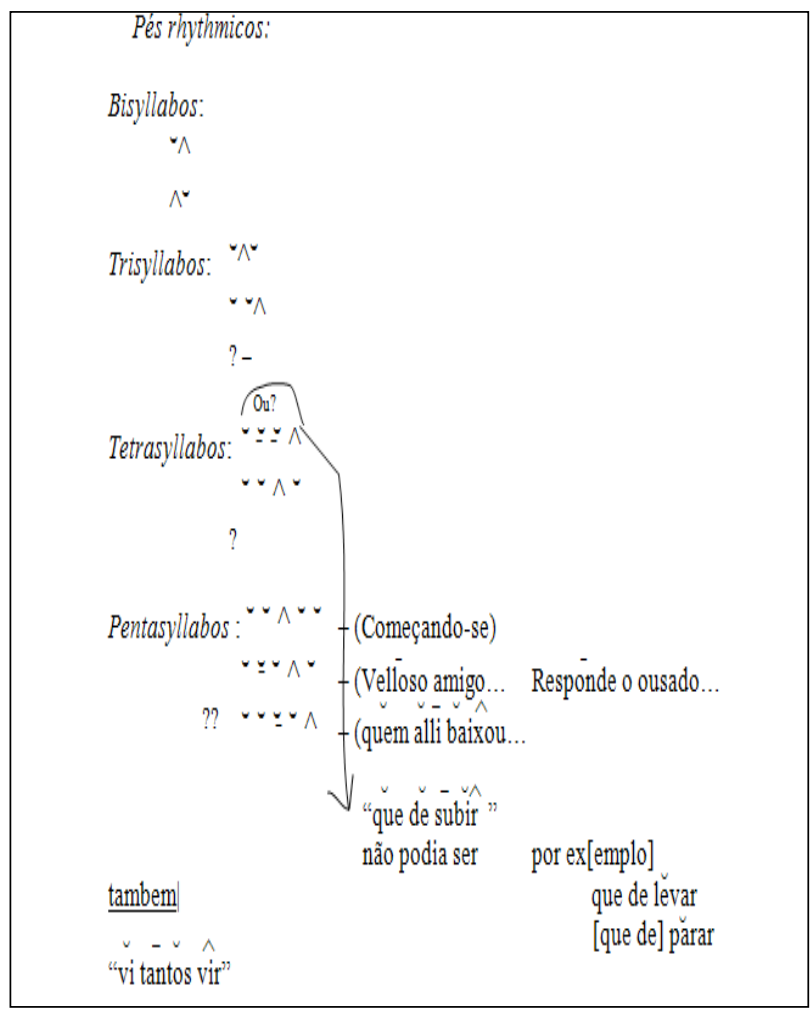

Detail $\left(14^{5}-37^{\vee}\right)$ [Pessoa quotes here passages from Os Lusíadas (Chant V, stanza 35, 11. 2-6).]

Several stress-units (left figure) constructed upon what Bridges' ears found in an English stressed verse, as he himself stated (1901: 88), were taken up by Pessoa (transcription on the right) (cf. FERRARI, 2010). Interestingly enough, these sketches or proposals provided by Bridges back at the turn of the Twentiethcentury partially overlap with a classification of metrics within the generative framework according to the principle of dactyl asymmetry (metrics with left-branching dactyl vs. metrics with 
right-branching dactyl) ( $c f$. PRINCE, 1989: 55). But before further elaborating on this point, let us come back to Pessoa's scansion of Camões' verse with the inclusion of the article $o$ :

\section{Albuquerqu' o|terribil| Castro forte.}

Pessoa's scansion is a mere application, modulo anacrusis, of the first of Bridges' britannics, which he also called midstress trisyllabic, and the third type of the quadrisyllabic feet, respectively. In fact, when we look at both models, we observe that, except for the first of the quadrisyllabic and the second and third of the five-syllable forms, the rest of Pessoa's «pés rhythmicos» have been directly copied from the English prosodist.

By simplifying the meaning of Bridges' symbols, which besides stressed and unstressed syllables also represented their length, Pessoa's have the following value: $\left({ }^{\wedge}\right)$ accented syllable, $(\cup)$ unaccented syllable, $(-)$ syllable with a secondary accent. It's within the realm of accents, testing and applying Bridges' models, that Pessoa will continue scanning different verses from Camões' epic poem. Now, the last feet of the verse in question could have been scanned by Pessoa as follows:

\section{Castro forte}

One of the rules Pessoa formulates is that «[n]enhum pé rhy[tmi]co, a não ser o bisyllabo, pode começar por uma syllaba rhythmicamente accentuada. ou isto é so em Portuguez» (145$\left.37^{\vee}\right)$. Pessoa's doubt lies on the existence and/or applicability (in Portuguese) of one of Bridges' models, namely the falling trisyllabic $\left({ }^{\wedge \smile}\right)$, beginning with a stressed syllable. And if we look closely at Pessoa's «pés rhythmicos,» none of them, except for one of the bisyllabic ones, begins with an accented syllable, be it a primary $\left(^{\wedge}\right)$ or a secondary accent $(-)$. 


\section{On Generative Verse}

Most of Bridges' reflections on prosody and rhythm, covertly incorporated in his feet proposals, and which were to have a direct impact on some of Pessoa's verse analyses, find their counterpart in the Generative Grammar of Verse. This is most commonly known after the name Generative Metrics, a theory developed in the late 60 s from the former core of Roman Jakobson's teachings on the formal analysis of poetry. It is precisely to some disciples and students of the eminent Russian linguist that we owe the outset of the theory. Thus, Halle and Keyser (1966) and Paul Kiparsky's two seminal papers (1968a, 1968b) are considered to represent the inception of this line of research, later enriched with the notation systems and formalisms developed in the 70s and early 80 s within the autosegmental and metrical phonology framework. Piera (1980), Prince (1989) and Hayes (1989) can be referred in this regard. Prosodic Phonology, as put forward by Nespor and Vogel (1986, 2nd edition 2007), constitutes another essential cornerstone of Generative Metrics. Fruitful applications to the study of verse from a generative point of view have also been made in the frameworks of Parametric Theory (Hanson and Kiparsky, 1996), and Optimality Theory (Golston, 1998; Fikkert, 2000, among others). The latest date to bear in mind in this on-growing tradition is represented by Fabb and Halle's New Theory of Meter $(2008)^{20}$.

\footnotetext{
$\overline{{ }^{20}}$ Putting aside its combined and innovative use of already existing formalisms such as the metrical grid or the bracketed grid, which date back to the early days of Metrical Phonology in the 80s, this theory separates itself from more traditional views within the generative framework on one fundamental theoretical assumption: «In our approach, rhythm and meter are quite distinct; in the traditional approach, rhythm and meter are two sides of the same coin» (HALLE and FABB, 2008: 24-25). Clarification is further provided as to the notational differences with previous approaches within the generative metrics school: «Our metrical grid is thus fundamentally different from the metrical grid proposed for poetry by Hayes (1983), which is not generated by iterative rules» (Halle and Fabb, 2008: 24, n. $8)$. Besides, the theory moves away from constraints back towards rules, while relying on the proposals for prosodic analysis (and particularly, for the analysis of word-stress) developed by Idsardi (1992, 2009) and Halle and Idsardi (1995). For a brief summary and criticism of the basic tenets and shortcomings of the New Theory, see RIAD (2010).
} 
It is of the utmost importance to notice that our purpose in this paper is not to argue for an overt formal connection between Bridges-Pessoa and the aforementioned authors, but rather to establish the common ideological substance to both BridgesPessoa and the modern generative metricists, and which tells them all apart from the dominant tradition in the preceding times $^{21}$. In other words, we will not be claiming that Bridges' essays on the feature of verse rhythm known as syntagmatics ${ }^{22}$ make him a generative metricist avant la lettre, but just stating some important analogies between the hidden laws of his analysis regarding feet-inventory and some of the basic assumptions of the Theory of Meter in a generative framework. ${ }^{23}$

The basic tenets of the Generative Theory of Meter can be formulated in a very simplified manner as follows:

Generative metrics assumes an atomic model, in which all surface constituents of the verse architecture (mainly, feet, dipodies and cola) derive from a very limited number of simple forms by means of a finite set of rules ${ }^{24}$. Poetic lines in the output are then the result of a finite derivation from the underlying

${ }^{21}$ Furthermore, the reader should keep in mind that the fact that Pessoa resorts to Camões in order to illustrate his proposed scansions would eventually allow us to pose two intriguing questions, which unfortunately cannot be addressed in the scope of the present paper, namely: (1) Can we attest any relevant language (more specifically prosodic) drift in the language from Camões' time to Pessoa's? (2) Have the metrical conventions changed in the centuries spanning between the two authors?

${ }^{22}$ A term first introduced in the English metrical tradition by Bridges himself in 1898, as Professor Martin J. Duffell has kindly pointed out to us (personal communication).

${ }^{23}$ Such correspondence is far from spurious or from a mere theoretical artifact with no basis on reality. In fact, I am not the first author to propose a connection between Bridges and generative metrics ( $c f$. DufFell, 2008: 194). The discussion and eventual controversy among scholars would rather refer to the extent and depth of such connection.

${ }^{24}$ These ideas are already present in poetics in the early decades of the Twentiethcentury in authors contemporary to Fernando Pessoa such as Paul Valéry or Velimir Khlebnikov. In the Iberian Peninsula, for instance, we find a modulation of those concepts, for instance, with the invention of the Máquina de trovar («Versifying Machine») by Jorge Meneses, one of Antonio Machado's apocryphs. This, however, is more focussed on the generation of complex poetic motives, which are then to be provided with an adequate rhythmical skeleton. Therefore, such concepts have to be seen as part of the Zeitgeist of the first decades of the Twentieth-century. 
abstract metrical pattern through a language-specific set of metrical rules and prosody-meter mapping rules, which together instantiate universal principles of organization.

A contrast between primitive and derived forms is thus implied within the theory. For instance, long constituents such as ternary feet (dactyls, amphibrachs and anapests) are generated by branching of the weak or strong position of a basic binary foot (iamb or trochee). More complex structures such as quadrisyllabics or five-syllable feet are formed analogously. ${ }^{25}$

If we now turn to a specific part of our corpus, that is, to the metrical annotations Pessoa borrowed from Bridges, we observe that the British prosodist organizes his material, namely, his feet, according to some principles he does not make explicit. Foremostly, it should be noted that only a subset of all possible combinations is considered, so Bridges obviously must have taken some theoretical criteria into account when constraining his repertoire. Now, which are those constraints and what is their nature? The logic of our research requires that we first recall the three basic principles of the architecture of verse, for they will allow us to establish the due analogies with the issue at stake. ${ }^{26}$

Those three principles must, however, be preceded by a complementary clause, which we may call the basic assumption of a Theory of Meter. Together they build up the logical system of verse craftsmanship.

\section{Basic Assumption of the Theory of Meter:}

THE HIERARCHICAL NATURE OF METRICAL STRUCTURE: Metrical structure is not a mere linear sequence of strong [S] and weak [W] positions, but rather a well-organized hierarchy of constituents exhaustively integrated in upper levels. The most intuitive visual representation of this idea is provided by the Metrical Hierarchy (HAYES, 1989, see below). ${ }^{27}$

$\overline{{ }^{25} \mathrm{~A}}$ more detailed account of this central issue can be found towards the end of this section.

${ }^{26}$ The principles we lay are roughly after Hayes (1989) and Prince (1989).

${ }^{27}$ This basic assumption is by no means privative of the generative approach or even of the poetic avant-garde. Rather, it might be considered the most widely-spread assumption in the Art of Verse in History. As a matter of fact, most of the familiar terminology (be it of Sanskrit origin, be it from the Greco-Roman tradition) stems 
1. BINARITY: all metrical structure is binary. This implies that metrical feet are, in principle, maximally disyllabic. Ternary (and eventually more complex) structures are explained by inner splitting or branching of one or more constituents. Thus, for instance, the well-known phenomenon of resolution allows for two submetrical positions within a metrical position, opening then the possibility of two syllables filling just one metrical slot and generating trisyllabic feet ${ }^{28}$.

2. UNIFORMITY: the labelling for strong and weak positions [S / W] remains constant throughout the whole tree structure. In other words, Foot $[\mathrm{F}=\mathrm{MP} \mathrm{MP}]$ and Metron $[\mathrm{D}=\mathrm{F} \mathrm{F}]$ are uniformly labelled for the $\mathrm{S} / \mathrm{W}$ relation; either [WS] at both levels or [SW] (Prince, 1989: 55) (see Metrical Hierarchy below).

3. TACTUS LEVEL HYPOTHESIS: «The tactus level hypothesis states that the MP has the rhythmic status of the musical beat» (Prince, ibidem). That is to say, no free assignment of S / W within the foot is permitted. In practical terms, the Tactus Level Hypothesis is responsible for restrictions on the inventory of feet within the theory. Were it not for it, four more possible structures would be allowed ( 2 additional anapests [[WS]S] and [W[WS]] plus one additional dactyl [S[WS]] and amphibrach [[WS]W]). As a matter of fact, it might be argued that the Tactus Level Hypothesis finds a physical correlate in the opposition between thesis and

from it. However, some proposals were originally made within the generative framework which advocated a serial theory of meter ( $c f$. Halle and KeYSER, 1966; MAGNUSON and RYDER, 1970; KIPARSKY, 1975). For criticism of these theses, illustrated with regard to the Serbocroatian epic verse, deseterac, $c f$. PRINCE (1989: 46-47). Alternative evidence in favor of the inner structure of this particular meter can be found in García Calvo (2006). Fabb and Halle's New Theory of Meter (2008) could be considered an intermediate or eclectic solution in this regard.

${ }^{28}$ Even if there are subtle differences between both concepts, as attested in the typological study of versification systems worldwide, for the purposes of the present paper they may be taken as synonyms. The Hierarchy presented here is a synthetic version of several proposals, most significantly by Hayes (1989) and Prince (1989). 
arsis within the Greek tradition of the rhythmikoi, as well as in the rules regulating their eventual splitting. As the reader may already know, thesis and arsis represent the two positions of the basic movement for the beat of a stick on the floor (a brief history of the emergence and evolution of such terminology is sketched in Garcia Calvo, 2006).

Every verse is thus seen as a particular and language-specific instantiation of the Metrical Hierarchy:

\section{Metrical Hierarchy}

Line

Colon or Dipody ${ }^{29}$ (D)

Metrical Foot (MF)

Syllable or metrical position (MP)

Submetrical position (mp)

With the help of the Metrical Hierarchy, we can represent the two most common varieties of the classical Portuguese decasyllable in the following fashion ${ }^{30}$ :

${ }_{29}$ «In Portuguese, Catalan and Provençal, meters are named after the number of their (projected) syllables up to and including the last lexical stress in a standard line. Works on Italian and Spanish add one syllable to this count, thus treating paroxytonic lines as the paradigm case. Hence the Portuguese decasilabo is equivalent to the Italian endecasillabo, etc.» (Carlos Piera in Fabb and Halle, 2008: 97). From a structural point of view, the Portuguese decasyllable corresponds to the English iambic-pentameter, even if their surface manifestations may sometimes differ greatly. The origin of both in its current productive form goes back to the borrowing of the Italian hendecasyllable at the beginning of the Sixteenth-century (cf. CunHa and Cintra, 1984; Gasparov, 1996, Hanson, 1997). A good summary of the historical path of the Portuguese decasyllable can be found in CARVALHO (1981b). For a general view of the typology of verse adoption and metrical change cross-linguistically, see ARIAS (2003).

${ }^{30}$ Binarity is not as pervasive through all levels of linguistic constituency as our somewhat pedagogical presentation may suggest. Thus, Metrical Stress Theory (Hayes, 1995), the theory responsible for the study of Lexical Word Stress and thereby for offering the prosodic basis for the mapping with verse structure, treats languages with fixed word-stress like French as made up, at the Prosodic Word Level, of unbounded (i.e. neither binary nor ternary) feet. However, for a language with free distinctive stress like Portuguese such analysis plays no role whatsoever. For an extensive analysis of the nature of resolution, see HANSON (1993). 


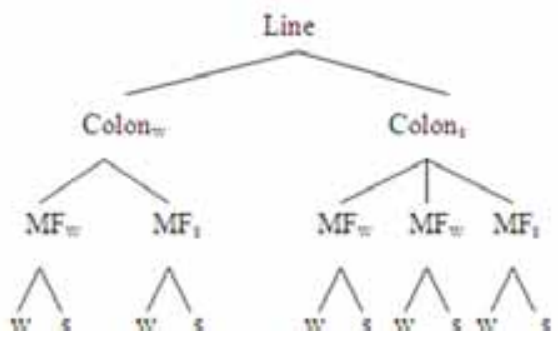

For the sake of visual simplicity, we have preserved ternay cola, even if further branching is needed to achieve complete understanding of their inner structure. As it can be observed, the two tree-structures abide by the above-mentioned Principle of Uniformity, which rules out configurations of the type in (a) and (b), preferring the ones in (c) and (d):

(a) *Dipody with iambic alternation of trochaic feet

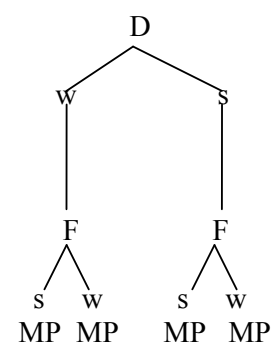

(c) Pervasively iambic Dipody

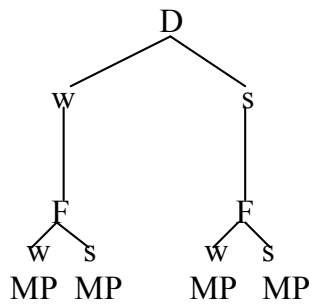

(b) *Dipody with trochaic alternation of iambic feet.

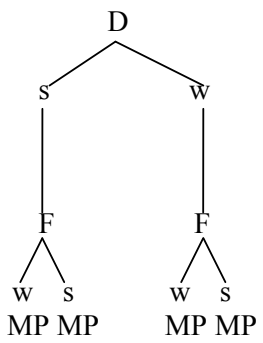

(d) Pervasively trochaic Dipody

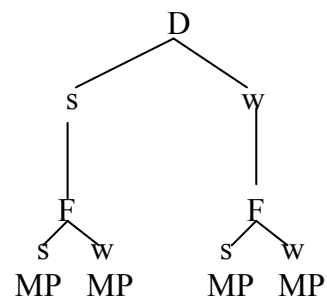


In this particular case we are taking the Portuguese decasyllable to consist of five metrical feet with right-headedness (that is, where the last syllable in the foot bears prominence, in whichever form the verse tradition determines; here prominence is implemented via stress; it is the structure in [c], which is the only relevant to us). If we were dealing with, say, a trochaic tetrameter (as in the Spanish octosyllable or many English folksongs), we would have to resort to (d).

After the required analytical tools have been already presented, it is time for us to return to Bridges' "stress-units» and establish the connections to the basic assumptions and principles of the Generative Theory of Meter. The reader should bear in mind, however, the epistemological remark we advanced at the outset of this section.

To begin with, we must consider the binary feet. As we now know, they are the primitives of the generative approach; but how does Bridges render them? He makes a distinction between right-headed feet (iambs) and left-headed feet (trochees), which he equates to his rising disyllabic and falling disyllabic feet, respectively (see fig. in section II). However, due to the contrast in length, his particular notation leads to a further categorization within each group. Hence, the weak position of the rising disyllabic (or iamb) may be occupied by either a long (-) or a short $(\cup)$ syllable, thus leading to the configurations $-^{\wedge}$ and $\cup^{\wedge}$. An analogous reasoning and procedure goes for the trochees $\left(^{\wedge}\right.$ - and ${ }^{\wedge} \cup$, respectively $)^{31}$.

If we now move onto the ternary feet, we have seen that within the standard Generative Theory of Meter they come up as the result of a derivation by splitting or inner branching of constituents. Now, do we find something analogous in Bridges? Certainly, no overt derivation of the form $\mathrm{A} \rightarrow \mathrm{B}$ is found; that does not preclude, however, some generative-like criteria from being reconstructed. Bridges does refer to the dactyl and anapest

$\overline{{ }^{31}}$ This somewhat murky and confusing notation suggests that Bridges has departed from a purely metrical system to reach a syllabo-metrical versification. For a detailed account of a typology of verse systems, see GASPAROV (1996), TSUR (1998) or AROUI (2009). Those distinctions (and others relevant for metrical typology) can be traced back to JAKOBSON and Lotz (1941), LotZ (1960) and LeVY (1971). 
meters in quite the conventional way, while still assigning them «rising» and «falling» patterns (1901: 97). Thus, dactyls would correspond to «falling trisyllabics» whereas anapests would be labelled as «rising trysillabics.» Other than this terminological idiosyncrasy, there is nothing here that does not express mere conventional knowledge. ${ }^{32}$ Nonetheless these two are not the only trisyllabic instances the British metricist considers. It's upon consideration of Bridges' 4th group (his second group of trisyllabics), the so-called, britannics -or mid-stress trisyllabics, that we first find evidence in favour of a generative-like constrained grammar of meter in our prosodist. Some metrical constraints can be derived out of the surface forms Bridges provides as possible feet:

A. Just one $(-)$ position per line is allowed. In other words, configurations of the form $(--)$ are banned, no matter whether the long positions are adjacent or not. For the sake of simplicity, from now on we will refer to this constraint as $(*--)$.

B. Middle ${ }^{\wedge}$ (abbreviated as MID $^{\wedge}$ ) states that odd-numbered meters should have a stressed $(\wedge)$ middle position.

It is precisely the interplay of those two constraints that will yield us the resulting surface forms Bridges proposes. Crucially,

$\overline{32}$ It might be argued, though, that Bridges seems to return at this point to a purely tonic system based on stress contrast alone, for otherwise he should also be including feet of the form $\cup-^{\wedge},-\cup^{\wedge}, \wedge-\cup, \wedge \cup-$, that is, feet where both the contrasts stressed-unstressed and long-short are present and annotated. Instead, he seems to equate the $\cup$ marks with unstressed syllables. The existence of the binary foot $\wedge$ - among his proposed patterns would then support this view, since it would come to prove that ${ }^{\wedge}$ should be construed as being indifferent or neutral with regard to length (otherwise the banned configuration - - would crop up) or, in a somewhat different phrasing with yet the same results, that the specification for stress overrides length features, making them somehow disposable. In our view, things are a little bit more complex than that. Certainly, Bridges never abandons the idea of a stress group, that is, of a grouping of syllables or metrical positions hovering around an only stress which attracts them like a magnetic field. As a matter of fact, we find one and only one ${ }^{\wedge}$ mark per feet in all of his proposed «stress-units». But it is also fair to say that every time Bridges retreats from a syllabometrical position he does so to defend a syllabotonic position, syllable counting remaining a fundamental structuring principle of the feet and the lines. It is probably under the underlying assumption of some sort of saturation of metrical positions that the ban against feet of the form $--^{\wedge}$ or ${ }^{\wedge}--$ is to be understood. 
this does not only apply to the britannics, but also to all other longer patterns. If we assume, very much along the lines of Optimality Theory ${ }^{33}$, that different Grammars of Verse result from different rankings of universal and minimally violable constraints (where A $>$ B expresses dominance of A over B, that is, the idea that violations of $A$ are more crucial to rule out candidates than violations of $\mathrm{B}$ are), two relative rankings of constraints are possible in our scenario (assuming they cannot be equally ranked), namely:

\section{Ranking 1:}

$\operatorname{MID}^{\wedge}>>*--$

This ranking, in which $\mathrm{MID}^{\wedge}$ is not dominated (and not even minimally violated) would account for the $4^{\text {th }}$ britannic in Bridges' repertoire $\left(-^{\wedge}-\right)$. The opposite ranking of constraints, that is,

Ranking 2:

$*-->>\operatorname{MID}^{\wedge}$

rules out what we might call «non uniform trisyllabics», that is, feet which include two different specifications for length, while allowing an initial or final stressed position. None of those four patterns $\left(\cup-\wedge,-\cup^{\wedge}, \wedge-\cup^{\wedge} \cup-\right)$, already mentioned in endnote 31 , is included among the britannics.

So much for the alleged conflict between the two proposed constraints. Besides, we have two further scenarios, with their associated feet, which do not respond to a conflict situation. Firstly, we find the case in which no conflict arises, because there is no single violation of any of the two constraints. That is precisely what happens with the remaining three britannics in Bridges' inventory $\left(\cup^{\wedge} \cup,-^{\wedge} \cup, \cup^{\wedge}-\right)$. Those first three britannics are thus to be seen as unmarked when compared to the $4^{\text {th }}\left(-^{\wedge}-\right)$.

${ }^{33}$ Prince and Smolensky (1993); McCarthy and Prince (1993). For its application to the analysis of poetic language and verse, see Hanson and Kiparsky (1996). The reader may have already noted that in the somewhat eclectic synthesis of different trends within generative metrics which the present paper represents we are taking some criteria or constraints to be (minimally) violable, within the spirit of Optimality Theory, while others (such as the correspondence or alignment between word-final and caesura) are construed as being absolute. This has to be taken at this point as a heuristic procedure, since an exhaustive motivation for each particular case would constitute the topic of a specific paper. 
Secondly, a case emerges in which no conclusive evidence for a hierarchy between the two metrical constraints at stake is found, since the feet considered $(--\wedge, \wedge--)$ violate both of them in an equal fashion, by having two long metrical positions at play, while at the same time allowing for non-medial ${ }^{\wedge}$.

It should be pointed out that the only britannic Pessoa borrows from Bridges, namely the foot $\cup^{\wedge} \cup$, happens to be not only an unmarked one, as expected on the grounds of universal tendencies of cross-linguistic metrical adoption, but, most significantly, the most unmarked one, the unmarked Britannic par excellence ${ }^{34}$. Indeed, neither of our two constraints nor, distinctively, the particular instantiation of the Uniformity Principle we have called the requirement for «uniform trisyllabics» is violated here.

Now, these constraint rankings are by no means arbitrary. On the one hand, they are reasonably restrictive with regard to the feet inventory, permitting just 6 out of 12 possible logical combinations $^{35}$. On the other hand, and most crucial to the purpose of this paper, they clearly relate to the predictions made by the Uniformity Principle and the Tactus Level Hypothesis ${ }^{36}$.

Consideration of Quadrisyllabics turns out to be particularly telling. For instance, the blatant omission of choriambs (feet of the form S W W S) among the proposed patterns needs to be

\footnotetext{
${ }^{34}$ Since it simultaneously respects $\operatorname{MID}^{\wedge}$ and $*--$, and does so by filling the marginal edge positions with $\cup$, thus forming the lightest or least saturated foot from a syllable-weight perspective.

${ }^{35}$ Considering britannics as well as all possible trisyllabic combinations either with initial ${ }^{\wedge}$ or with final $\wedge$.

${ }^{36}$ Thus, we have seen that the exclusion of feet such as ${ }^{\wedge} \cup-$ or $^{\wedge}-\cup$, for example, is due to a request for uniformity in the unstressed positions which somehow echoes the second principle of a Generative Theory of Meter as defined at the beginning of this section. In fact, even if no strong isomorphism can be drawn, some of the banned structures overtly correspond to those ruled out by the Principle of Uniformity, such as the so-called right-dactyl [S[SW]]. With respect to the Tactus Level Hypothesis, which demands that every metrical position should be equated with a musical beat, some of the configurations ruled out by it (Prince, 1989: 55), such as the anapest ([W[WS]]), might be taken to overlap with the feet excluded by the joint violation of $\operatorname{MID} \wedge$ and $*--$, that is, $\wedge_{-}-$and $-{ }^{\wedge} \wedge$. Describing in surface phonetic terms the nature of such correlations, and establishing the semiotic equivalences between the different notation systems, constitutes an often challenging and awkward task, which goes well beyond the scope of the present paper.
} 
taken into account. This otherwise striking fact, if considered in isolation, finds a direct and easy explanation when integrated with the other foot types, particularly with the trisyllabics. Thus, none of the two feasible translations of the notation, namely, $-\cup \cup-$ or $^{\wedge} \cup^{\wedge}$ are well-formed. The former would violate * -- , while not presenting any medial ${ }^{\wedge}$, whereas the latter would violate the requirement of just one ${ }^{\wedge}$ per foot. Analogously, the challenges posed by the restrictions upon the five-syllable rhythms disappear when our constraints are taken into account.

Summarizing, the predictive power of our theory and restrictions, aimed at revealing the covert metrical grammar Bridges was taking into consideration, does not only refer to the britannics, but to all other feet beyond binarity.

Five-syllable feet, which Bridges takes to be very marginal among his stress-unites, are now hardly a mystery for the analyst. Why does Bridges just pick the pattern $\cup \cup^{\wedge} \cup \cup$ among all possible combinatorial possibilities? The answer should be pretty straightforward to the reader now. The argument runs parallel to the pick of the britannic by Pessoa. It is the joint effect of the constraint $\mathrm{MID}^{\wedge}$ and the instantiation of the Uniformity Principle which dictates the chosen foot here. Once again, it results in the most unmarked option available.

\section{Prosodic Phrasing in Pessoa's Scansion of Camões: some cues}

Last but not least, a very brief account of some of the theoretical implications for phrasing brought up by Pessoa's scansion of Camões seems mandatory. From a historical perspective, if we review the main applications of metrics to phonological research within the generative framework, we find that:

A. Metrics has been used in classical generative phonology to argue for the psychological reality of intermediate representations (KIPARSKY 1968a, 1968b).

B. Use of metrics has also been made to help establish the limits of prosodic constituents in diachronic research (NESPOR and VoGEL, 1986, $2^{\text {nd }}$ edition 2007, among others). 
Those two approaches were particularly aimed at answering some research questions with the ultimate goal of refining the description of the relation between language and meter. Such questions can be formulated as follows:

Q1: Is there a way to justify the reality of some of the levels of linguistic representation on the grounds of versification data?

Q2: Is it possible to get well-grounded evidence of prosodic constituency through metrics despite the lack of direct information?

We will only touch upon Q2 in this remaining section of the paper. In order to do so, we must keep in mind the main assumptions on phrasing made in metrical research. They can be summarized in two points: (1) Prosodic phrasing and meter are tightly intertwined, so that insight into one of them will contribute to clarify any ambiguity regarding the other; (2) a great deal of metrical rules are prosody-dependent. This dependency can be expressed in different ways, with the help of various formalisms. ${ }^{37}$

Metrical Theory and its interplay with Prosody somehow mirrors, from a logical point of view, the Syntax-Prosody interface. As much as we may talk about three main views of the latter (INKELAS and ZEC, 1995; ZEC 1998, among others) ${ }^{38}$, which only partially overlap with each other, we can also accordingly apply this very same logic when analysing the mapping between the abstract metrical pattern and linguistic material. However, we first need to outline a brief sketch of a typology of metrical rules, particularly of the two sub-categorizations within the group of rules based on boundaries of constituents:

Bounding Rules. We consider a metrical rule to be bounding if it only takes into account the prominence peaks which are defined within a given prosodic category (foot, phonological

\footnotetext{
$\overline{37}$ That is, correspondence based on relation, correspondence based on boundaries, and correspondence based on tree-structure. Here we will only pay attention to correspondence rules based on constituent boundaries.

${ }^{38}$ We will briefly address the topic of catalexis and its somehow counterpart resolution right before the conclusion.
} 
phrase, intonational phrase, and so on). Depending on the constituent edge they are anchored at Bounding Rules adopt one of the following two configurations:

a. Right Edge Rules seek to avoid the configuration:

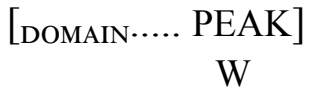

That is, they prevent a prosodic peak from occupying a weak metrical position. An example of such a rule would be the particular instantiation of the English iambic pentameter by which stressed syllables are ruled out of the odd (and therefore weak) metrical positions in the line.

b. Left Edge Rules, rather than banning some sequences, can override other metrical rules, thus allowing for the wellformedness of otherwise avoided configurations. They apply to forms of the type:

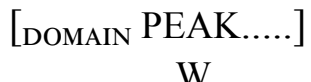

In the example of the English iambic pentameter mentioned above, a Left Edge Rule would allow the leftmost stressed syllable within a Phonological Phrase to occupy a weak metrical position, thus dominating or overriding the requisite expressed by the corresponding Right-Edge Rule.

Edge rules provide key cues for phrasing. We will now illustrate how a bounding metrical rule (more precisely, a Left Edge Rule) can be derived from Pessoa's analysis of Line 7 of the $14^{\text {th }}$ Stanza from the First Chant of Os Lusiadas, thereby shedding light on the prosodic constituent structure underlying it. If we turn to Pessoa's scansion of Camões' verse, we observe that his proposal is ternary:

Albuquerque | terribil, | Castro forte | 
According to the Prosodic Hierarchy (cf. Hayes, 1989) we could analyse the verse in the following fashion, dividing it into two phonological phrases:

\section{Albuquerque terribil,] $\phi$ Castro forte] $\phi$}

This resulting mismatch between a ternary metrical division and a binary phonoprosodic grouping requires some explanation. If we assume that the caesura of the decasyllable meter should be aligned with the right edge of a phonological phrase (as evidenced by phenomena such as the prohibition of synalepha across caesura boundaries). That precludes the possibility of «terribil» and «Castro» grouping together here. Now, why is it that we do not find any further prosodic division within the corresponding hemistichs from the phonological and prosodic point of view? Or, why does Pessoa avoid going a step further and proposing a quaternary scansion of Camões' verse? Our analysis must provide a reasonable and theoretically sound account for the exclusion of the former:

* Albuquerque] $\phi$ terribil,] $\phi$ Castro] $\phi$ forte] $\phi$,

as well as of the latter:

* Albuquerque $\mid$ terribil, $\mid$ Castro $\mid$ forte $\mid$

These exclusions seem to be primarily driven by minimal size conditions. Thus, "Castro» and «forte» being disyllables, they can indeed build a foot, but not a legitimate phonological phrase, which demands binary constituency, that is, two feet, in order to be (optimally) well-formed. In the case of the second hemistich, then, analogous considerations apply both at the metrical and at the prosodic level. It is in the first one that those domains diverge, leading to different divisions. "Alburquerque» saturates all the metrical positions available, making a colon or dipody of its own, and leading to a separate grouping of «terribil.» However, from the prosodic point of view both words are grouped within the same phonological phrase, since no maximum size requirement applies here (as far as the minimal size condition has been fulfilled by each of them). 
Now, when the mapping between the linguistic material and the abstract metrical pattern is considered, the picture becomes much more complicated, to the point where some of the assumptions and analyses made above have to be abandoned. Particularly, if we turn our attention to the interplay of the caesura boundary with the specific prosodic constituency of the verse, some critical issues come to the fore. Let us assume for now the metrical pattern of alternation proposed for the Portuguese decasyllable in Section III, namely, that of an iambic pentameter (acatalectic) $^{39}$. The poet taking up such model has ten metrical positions at his or her disposal, which are most frequently filled with eleven syllables, the last one being overseen when posttonic. There are two possibilities regarding the placing of the caesura (//), resulting in either a $6+4$ division or in a $4+6$ partition of the line. In our case, this plays out as follows:
a) $* 6+4$
Alburquerque terribil, Castro for(te)

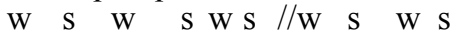

This scansion is undoubtedly most coherent when thinking about mapping the caesura with the phonological phrase boundary:

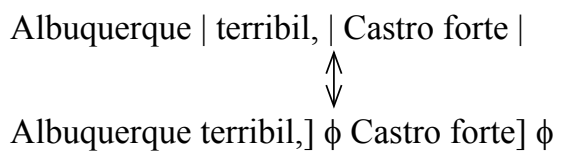

However, such analysis does not hold in this particular case, since the specific nature of the linguistic material at hand strongly militates against it. The prosodic word «terribil» would then split between the two hemistichs, which violates all basic rules of metrics regarding the alignment of meter and prosody:

$$
\begin{gathered}
\left.{ }^{*} \text { Terribil }\right]_{\mathrm{Pwd}_{\mathrm{d}}} \\
\mathrm{w} \mathrm{s} / / \mathrm{w}^{40}
\end{gathered}
$$

${ }^{39}$ It should be pointed out that such rules come to crystallize and stabilize in the Renaissance period, after a long time-span of hesitation and variation during the Middle Ages, in which this kind of break or tmesis was not ruled out.

${ }^{40}$ This argument is indeed independent from the particular form of representation 
In other words, if we do not allow for «terribil» to extend over the two verse halves, then the two resulting hemistichs would be ill-formed; the first lacking a metrical position to accommodate that trisyllabic word and the second having one too many for its only three relevant syllables (the post-tonic not playing any role for count, as already mentioned). Therefore, we cannot but exclude this scansion, for it is not feasible.

If we now consider the other possibility for scansion of the line, we have:

\section{b) $4+6$}

Alburquerque terribil, Castro for(te)

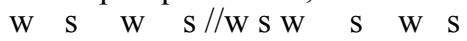

This option does not critically violate any fundamental principle of metrics. No prosodic word is split by the caesura nor do we find missing or stranding metrical positions in any of the hemistichs. However, it is by no means free from some problems. Two of them need to be referred here. To begin with, the caesura after «Alburquerque» would not coincide with the right edge of the phonological phrase we have assumed thus far. Secondly, while the second hemistich presents a perfect mapping between stressed syllables and strong metrical positions, the first hemistich systematically fills strong positions with unstressed syllables and weak positions with stressed syllables, thus creating incoherence along the whole line. Now, how can we tackle these two problems? The next paragraphs constitute an attempt to offer a solution.

With regard to the first aspect, we may just be wrong accepting a binary prosodic analysis of the given line, construed as made up of only two phonological phrases. Perhaps we should pose a ternary division, which would consequently match the metrical pauses Pessoa proposed. Hence our phonoprosodic scansion should be as follows:

Albuquerque] $\phi$ terribil, $] \phi$ Castro forte] $\phi$

one adopts for dealing with prosodic dependencies. There is no need to assume the Prosodic Hierarchy at the basis for it to hold. It suffices to assume, as PIERA (2009: 287) does, that, in languages with lexical stress, the units of intonational phonology are built on a layer of stress marks, which is universally accepted by all authors working within the generative framework. 
Accordingly, the main pause, dictated by the caesura break, would be after "Alburquerque,» which is somewhat counterintuitive (given that, from a syntactic standpoint, the line constitutes a neat binary apposition), but by no means impossible. Each minimal size requirement would still apply all throughout. As for the second problem, a more detailed inspection reveals it is not such. Not only are cases of inversion well-attested crosslinguistically in different meters, but they most often occur in that very context, that is, at the beginning of the line and/or of a phonological phrase. We would simply have to formulate a LeftEdge Rule of the type:

[Phonological Phrase $\left.\frac{}{\mathrm{W}}\right]$, or, in an alternative notation, $\phi\left[\frac{}{\mathrm{W}}\right]$ W

This rule, when (optionally) applied, overrides the natural distribution of prominent and unprominent syllables (in this case, with regard to stress) in strong and weak positions within the first metrical foot of the line, thus allowing for inversion, that is, for a stressed syllable occupying a weak position at the beginning of the verse. Yet, we still have to account for the second metrical foot, «-querque». We cannot reformulate the Left Edge Rule with reference to the constituent foot, since that would result in a very loose line (all initial foot positions would then be entitled then to trigger inversion). Therefore in order to get around this troublesome and weakest point of our theory, we either permit some $a d$ hoc provision (essentially, a local rule of the type W S $\rightarrow \mathrm{S} \mathrm{W}$ ), which is not altogether exceptional in the generative metrics framework, or we accept a violation of the correspondence pattern in that given context $t^{41}$.

$\overline{{ }^{41} \mathrm{We}}$ cannot say, for instance, that a parameterization $\mathrm{S} \Rightarrow \neg \mathrm{U}$ prevails instead of $\mathrm{W}$ $\Rightarrow \neg \mathrm{P}$ in the rest of the line, since the foot «querqu» does not confirm that. See Hanson and Kiparsky (1996: 290): «The PROMINENCE SITE parameter establishes the metrical asymmetry between strong and weak positions. This is achieved by restricting either strong positions or weak positions, viz. requiring either (i) that strong positions contain no unprominent constituents $(S \Rightarrow \neg U)$, or (ii) that weak positions contain no prominent constituents ( $\Rightarrow \neg \mathrm{P}$ ). These constraints also occur in a weaker form, requiring respectively that strong positions contain at least one prominent constituent ( $\mathrm{S} \Rightarrow \mathrm{P}$, which allows resolution in strong positions), and that weak positions contain at least one unprominent constituent $(\mathrm{W} \Rightarrow \mathrm{U})$ ». 
Summarizing, an iambic-based $4+6$ scansion perfectly suits the mapping with well-formed prosodic phrasing, while at the same time adequately fitting most of the linguistic material (although in order to fully accommodate the first hemistich a pattern W S S W // W S W S W S should be put forward). On the contrary, a $6+4$ scansion leads to unsolvable conflicts at all levels of metrical analysis, as we have already seen. The $4+6$ scansion would also imply a Left-Edge Rule of line-initial inversion, as well as a local rule of inversion of metrical positions in the second foot of the first hemistich ${ }^{42}$. The analysis of the second hemistich would be straightforward. We must now ask ourselves a provocative question, namely, what if we departed from the iambic interpretation of the line ${ }^{43}$ ? Would we gain something by doing so? What would be the advantages and the drawbacks of such an approach? Would we somehow avoid the problems we have encountered thus far? Let us briefly consider the empirical results on our line from Camões. If we first turn to a scansion of the type $6+4$, we have:

$$
\begin{aligned}
& \text { * } 6+4 \\
& \text { Alburquerque terribil, Castro for(te) } \\
& \text { s w s } \text { w s w // s W S W }
\end{aligned}
$$

Here we find analogous insurmountable problems to those of the $6+4$ iambic scansion. The word «terribil» would once

$\overline{42}$ Strictly speaking, only the second foot, -querque, constitutes a real metrical inversion, in which the alternating positions have indeed been relocated. The LeftEdge Rule simply inverts the expected position of the stressed and unstressed syllables, while the pattern of strong and weak positions remains unchanged.

${ }^{43}$ This other view is by no means ungrounded. We would just be echoing some remarks in the philological tradition with regard to the trochaic rhythm of the decasyllable, or comments elaborating on the varied, flexible and complex nature of this meter. For instance, Cunha \& CinTra (1984: 684) provide an example from Camilo Passanha's sonnet «No Claustro de Celas», whose second line, «Primavera que durou um momento» should illustrate one of several further types other than the Heroic and Sapphic, particularly one with stress on the $3^{\text {rd }}, 7^{\text {th }}$ and $10^{\text {th }}$ syllable, which, even if not totally coincident with our verse line, does allow a trochaic interpretation of the first four feet, very much as «Alburquerque» would require. Another reflection which would come to harmonize with this alternative attempt is formulated in Spaggiari (2003: 173): «the Portuguese decasyllable exhibits an extreme variety of forms, rhythms and scansion patterns, all equally possible and codified in the poetic idiom; so that the only constant distinctive feature of the verse appears to be the compulsory accent on the $10^{\text {th }}$ syllable.» 
again extend across the break adopted by Pessoa's scansion, and no reasonable mapping between prosodic phrasing and metrical hemistich and pauses could be found. Besides, the first two metrical feet would be nicely formed, but at the high cost of a horrible second hemistich. Therefore there is no way we could privilege this analysis over the previous ones. What would then happen if we gave preference to the $4+6$ scansion, as we did with the iambic-based pattern?

$$
\begin{aligned}
& 4+6 \\
& \text { Alburquerque terribil, Castro for(te) } \\
& \mathrm{s} \text { W } \mathrm{s} \text { W } / / \mathrm{s} \mathrm{W} \mathrm{S} \mathrm{W} \mathrm{S} \mathrm{W}
\end{aligned}
$$

The caesura break fits perfectly and the first hemistich is extremely well-formed from the point of view of the mapping between stressed-unstressed syllables and strong and weak metrical positions. But, again, the second part of the verse turns out to be extremely ill-formed, with all its three strong metrical positions being occupied by unstressed syllables, while the three stressed syllables fall in weak metrical positions, which in the terms of Hanson and Kiparsky completely excludes any parameterization ${ }^{44}$. So a trochaic-based scansion does not bring us further, all other things being equal. Now, what would happen if we had a trochaic-based pattern, but, crucially, considered the last post-tonic syllable as well, that is, avoiding final extrametricality ${ }^{45}$ ? Given the mismatch between the actual

$\overline{{ }^{44}}$ It is worth noting that what seems to be at stake here, with an adequate first hemistich resulting in an ill-formed second half of the line, and vice versa, somehow mirrors Roman Jakobson's (1952) analysis of the Slavic epic verse. For Jakobson, the essence of that meter is the unresolved tension between the demands from the two hemistichs, which correspond to a "counting from the beginning» and «counting from the end», respectively. This struggle between a linear and a holistic recapitulative scansion typically leads to variation in syllable count and dislocation of the caesura (sometimes resulting in a ternary structure) and is deeply rooted in the musical origins of verse.

45 This should be distinguished from catalexis, which is the loss of the last weak metrical position, resulting in a truncated ending in strong position or thesis. Restoring final extrametricality is in principle independent from the meter considered being catalectic or acatalectic. The number of scansions suggested in this section could have been augmented by including catalectic versions of the meters, but, as the reader himself might want to proof, that would not bring any substantial improvement of the proposals. 
number of syllables and the number of metrical positions, one instance of (non-final) resolution should be called upon in the line, where resolution is defined as follows:

Resolution:<smiles></smiles>

The two alternative scansions for such proposal would give the following picture:

$$
\begin{aligned}
& 6+4 \\
& \text { Alburquerque terribil, Castro forte } \\
& \text { s w s } \quad \text { W s w // }
\end{aligned}
$$

The caesura falls smoothly after a phonological phrase boundary (allowing us, in fact, to keep binary phrasing) while at the same time getting a perfect mapping between meter and prominence units; provided we assume resolution of the second strong position in the line, which would come to embrace the syllables «-quer» and «-que».

$$
\begin{aligned}
& 4+6 \\
& \text { Alburquerque terribil, Castro forte } \\
& \mathrm{s} \text { W } \mathrm{s} \quad \mathrm{W} / / \mathrm{s} \quad \mathrm{W} \quad \mathrm{s} \quad \mathrm{W} \quad \mathrm{s} \quad \mathrm{W}
\end{aligned}
$$

Again, the placing of the caesura does not present any phrasing challenge, while the last two feet are built up in an elegant fashion. The first hemistich is also well-formed, and only the decision should be made as to whether resolution takes place on the first strong position after the caesura or on the first weak position of the second verse half. Since resolution of strong positions is more frequent, we have preferred the former option here.

All in all, both scansions are acceptable, although the $6+4$ alternative seems to fit in a more straightforward way. Finally, we should consider the results yielded by an iambic-based approach with no final extrametricality and one internal resolution: 
$* 6+4$

Alburquerque terribil, Castro forte

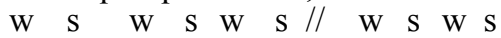

$* 4+6$

Alburquerque terribil, Castro forte

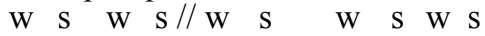

Nothing significant is gained by taking up those two scansions. As we can see, even if the caesura break is perfectly aligned with a right phrasing boundary, all feet but the third violate the basic matching principles (their stressed syllables, the $1^{\text {st }}$ and $3^{\text {rd }}$, filling weak metrical positions, while the $2^{\text {nd }}$ and $4^{\text {th }}$, unstressed, occupy the strong positions).

Summarizing, two possible scansion types are feasible for the Camões' line Pessoa has scanned. Either an iambic pentameter analysis with a $4+6$ hemistich division, a Left Edge Rule allowing initial inversion and a local rule for the second foot, or any of the two $(4+6$ and $6+4)$ trochaic-based scansions with no final extrametricality, that is, considering the post-tonic syllable into the proper metrical count. Its abundant formal machinery disfavours the choice of the first one, but we still think it is preferable to the other. The second option, albeit formally more elegant, overtly contradicts all traditional and generative accounts of the decasyllable meter in Portuguese, which end the count of the metrical positions with the last stressed syllable.

\section{Conclusions}

Metrics may provide evidence for the formation of a given prosodic constituent (e.g. in his scansion, Pessoa does not stress the $8^{\text {th }}$ syllable; in his system of stress-units -which follows Bridges to a great extent- there are no feet composed of two unstressed syllables, thus giving way to no division between «Castro Forte»). Several alternative scansions for the given line have been put forward and thoroughly analysed. An iambic-based $4+6$ scansion and two trochaic-based scansions without final extrametricality have been shown to be the only feasible solutions. The latter are counterintuitive with respect to traditional knowledge about the decasyllable in Portuguese, 
but formally simpler; the former requires a sophisticated implementation of formal machinery but is, on its turn, closer to empirical poetic practice within that given tradition. Each of them has consequences for phrasing in the line.

We have seen that Bridges' "stress-units» are substantiated in an implicit generative-like Theory of Meter, with significant predictive power. Its constraints help explain the ternary, quaternary and five-syllable meters the British author lists and Pessoa partially borrows. As we have seen, such a theory entails certain assumptions about meter generation, which are to a great deal parallel to those made by the Generative Theory of Meter as we know it from the late 60 s onwards. That does not amount to equating Robert Bridges with Morris Halle or Paul Kiparsky, but simply to acknowledge a common procedure of verse derivation and constriction.

Finally, we have also proved how metrical structure provides us with indirect evidence for prosodic phrasing, as illustrated in the case of the iambic-based scansion with a Left Edge Rule of Camões' verse, which obligatorily demands ternary phrasing of the line.

\section{Annex}

[14-36]

É preciso distinguir entre a pausa rhythmica e a caesura ${ }^{1}$. Por exemplo, no verso de Camoens

Albuquerque terribil, Castro forte ${ }^{2}$

é evidente que a caesura é depois da palavra terribil ${ }^{3}$, mas as pausas ${ }^{4}$ rhythmicas são

\section{Albuquerque |terribil, | Castro forte}

o que é facil de confirmar, lendo alto este verso e com correcta intonação; ver-se-ha que ha uma pausa natural (e rhythmica) por 
ligeira e vaga que seja depois da palavra Albuquerque. Uma tentativa para lêr aquelle verso ou como birhythmo ou como tendo uma pausa ${ }^{6}$ rhythmica depois da palavra Castro mostrará ainda mais a verdade ${ }^{7}$ ''esta asseveração.

A pausa, as pausas rhythmicas dependem só da rhythmica ${ }^{8}$; a caesura não é senão a pausa grammatical ${ }^{9}$.

Suppunhamos que Camoens houvera escripto, inserindo o artigo $o$

Albuquerque o terribil, Castro forte

O verso resultára (como a leitura immediatamente mostra/ rá/) num menos bem-soante. A ler o verso de modo ${ }^{10}$ que se oiça o artigo $o\left(\operatorname{sem}^{11} \mathrm{o}\right.$ ac-[36 $\left.6^{\mathrm{v}}\right]$ centuar indevidamente) achará um ouvido $^{12}$ sensivel ao rhythmo uma extranheza ${ }^{13}$ como que uma inabilidade rhythmica. E ha-a decerto e consiste em forçar a palavra Albuquerque a apropriar-se rhythmicamente do artigo $o$ que devia pertencer ao pé rhythmico dominado pela palavra terribil, de que aquelle artigo é proclitico ${ }^{14}$.

\section{Albuquerqu ${ }^{\text {ty }}$ o| terribil| Castro forte.}

Já sabemos que é uma lei do rhythmo (a violação da qual fére o ouvido, como no caso actual) que os encliticos e procliticos de uma palavra hão de pertencer-lhe rhythmicamente, fazer parte do pé rhythmico em que ella domina.

\section{Notar}

\section{Pois a nåo tens | á morte | 'scura d'ella}

$$
\text { [14-36] }
$$

Two loose sheets handwritten in black ink. On the verso, atop of the left margin, we read a number 2, underlined. Some passages from this document were first transcribed by Rita Patricio in Episódios da Teorização Estética em Fernando Pessoa (2008: 
100, n. 104). This document was first mentioned by Pauly Ellen Bothe (2003: 78, n. 31). ). The lines by Camões that Pessoa scanned here were taken from Os Lusíadas, Chant I, stanza 14, l. 7 and Chant III, stanza 127, l. 6.

\section{Genetic Apparatus}

$1 \mathrm{c}<\mathrm{e}>$ /alesura

2 in Episódios da Teorização Estética em Fernando Pessoa (2008: 100, n. 104) we read Albuquerque terríbil Castro forte

3 in Episódios da Teorização Estética em Fernando Pessoa (2008: 100, n. 104) we read terríbil

$4 \mathrm{a}[\mathrm{s}]<1^{\mathrm{a}}>$ pausa[s]

5 in Episódios da Teorização Estética em Fernando Pessoa (2008: 100, n. 104), we read Albuquerque | terribil | Castro forte] sem virgula após terribil

$6 \quad[\uparrow$ tendo $<\mathrm{a}>$ uma $]$ pausa $<$ do $>$

$7<$ est $>$ a verdade

8 do rhythmica ] in the original. We have corrected the contraction of the preposition. In Episódios da Teorização Estética em Fernando Pessoa (2008: 100, n. 104) we read do rhytmico

9 in Episódios da Teorização Estética em Fernando Pessoa (2008: 100, n. 104) we read gramatical

10 ler [ $\uparrow$ o verso] de modo

$11<$ mas $>$ sem

$12<0>[\uparrow$ num] ouvido

13 after the word extranheza the author closed the parenthesis that we have omitted.

14 en[ $\uparrow$ pro]clítico

15 Albuquerqu $<\mathrm{e}>/>$

\section{Bibliography}

ARIAS, Javier: «Sobre cinco clases de cambio métrico». Analecta Malacitana, 2003, XXVI, 1, pp. 49-72.

AROUI, Jean-Louis: «Introduction: Proposals for metrical typology.», in Jean-Louis Aroui and Andy Arleo (eds). Toward a Typology of Poetic Forms. Amsterdam: John Benjamins, 2009, pp. 1-39.

ATTRIDGE, Derek: Well-weighted Syllables: Elizabethan verse in classical metres. Cambridge: Cambridge University Press, 1974. [Ph.D. dissertation in 1972 with the title The Elizabethan Experiments in English Quantitative Verse]. 
BOTHE, Pauly Ellen: Poesía y musicalidad en las poéticas modernistas de Fernando Pessoa y T.S. Eliot: la Ode marítima. Tese de Mestrado em Literatura Comparada apresentada à Faculdade de Letras da Universidade de Lisboa, 2003. [Policopied text].

BRIDGES, Robert: Milton's Prosody; Classical Metres in English Verse by William Johnson Stone. Oxford: Henry Frowde, 1901. [Fernando Pessoa House, 8-64].

CARVALHO, Amorim de: Problemas de Versificação. Lisboa: Centro do Libro Brasileiro, 1981.

- Tratado de Versificação Portuguesa. $4^{\text {th }}$ ed. Lisboa: Universitaria Lisboa, 1981 [First edition: Porto, Author's edition, 1941].

-Teoría Geral da Versificação: A Metrificação e a Rima. Lisboa: Editorial Imperio, 1987.

CUNHA, Celso and Luís F. Lindley Cintra: Nova Gramática do Português Contemporâneo. 13 ${ }^{\mathrm{a}}$ ed. Lisboa: Edições João Sá da costa, 1997 [First edition: 1985].

DUFFELL, Martin J.: A New History of English Metre. London: Legenda, 2008.

FABB, Nigel and Morris Halle: Meter in Poetry: A New Theory. Cambridge, Massachusetts: Cambridge University Press, 2008.

FERRARI, Patricio: «Fernando Pessoa, poète-lecteur-théoricien: des expériences métriques et rythmiques entre-langues.». Loxias, revue en ligne de littératures française et comparée, $n^{\circ} 30$, Université de Nice Sophia-Antipolis, automne 2010, http://revel.unice.fr/loxias/index.html?id=6464

— «Fernando Pessoa y Alejandra Pizarnik: escritos, marginalia y otros apuntes en torno a la métrica y al ritmo». Bulletin of Spanish Studies: Hispanic Studies and Researches on Spain, Portugal and Latin America, volume LXXXVIII, number 2, University of Glasgow, 2011, pp. 221-248. - Meter and Rhythm in the Poetry of Fernando Pessoa. PhD dissertation presented at the Department of Linguistics of Universidade de Lisboa, 2012. [Policopied text].

FIKKERT, Paula: «Prosodic Variation in "Lutgart"», in Aditi Lahiri (ed.), Analogy, Levelling, Markedness. Principles of Change in Phonology and Morphology. Trends in Linguistics. Studies and Monographs 127. Berlin: Mouton de Gruyter, 2000, pp. 301-332.

FOWLER, Rowena: "Comparative Metrics and Comparative Literature.» Comparative Literature, Vol. 29, No. 4, Autumn, 1977, pp. 289-299

GARCÍA CALVO, Agustín: Tratado de Rítmica y Prosodia y de Métrica y Versificación. Zamora: Editorial Lucina, 2006.

GASPAROV, Mikhail Leonovich: A History of European Versification. Translated from Russian by Gerry Smith and Marina Tarlinskaja. Edited by Gerry Smith with L. Holford-Strevens. Oxford: Clarendon Press, 1996 [First edition in Russian, 1989].

GOLSTON, Chris: «Constraint-based metrics». Natural Language and Linguistic Theory, 16, 1998, pp. 719-770. 
HALLE, Morris and Samuel Jay Keyser: «Chaucer and the Study of Prosody». College English, 28, 1966, pp. 187-219.

HALLE, Morris and William J. Idsardi: "General Properties of Stress and Metrical Structure», in John Goldsmith (ed.), A Handbook of Phonological Theory. Oxford: Blackwell, 1995, pp. 403-443.

HANSON, Kristin: «Resolution: evidence from modern English metrics». Proceedings of the Annual Meeting of the North East Linguistics Society, 23, 1993, pp. 159-173.

- «From Dante to Pinsky: a theoretical perspective on the history of the modern English pentameter». Rivista de Linguistica, 9.1, 1997, pp. 53-97.

HANSON, Kristin and Paul Kiparsky: «A Parametric Theory of Poetic Meter». Language, 72, 2, 1996, pp. 287-335.

HAYES, Bruce: «A Grid-based Theory of English Meter». Linguistic Inquiry, 14, 1983, pp. 357-393.

- «The Prosodic Hierarchy in Meter», in Paul Kiparsky and Youmans, Gilbert (eds.). Phonetics and Phonology: Rhythm and Meter. San Diego: Academic Press, 1989, pp. 201-260.

- Metrical Stress Theory: Principles and Case Studies. Chicago: Chicago University Press, 1995.

HORACE: Euvres d'Horace. Texte Latin. Avec une étude biographique et littéraire, une notice sur la métrique et la prosodie dans les Odes et Épodes, des notes critiques, un index des noms propres et des notes explicatives par F. Plessis et P. Lejay. $3^{\text {ème }}$ éd. Paris: Librairie Hachette et $\mathrm{C}^{\mathrm{ie}}$, 1909. [Fernando Pessoa House, 8-263].

IDSARDI, William: The Computation of Prosody. Ph.D dissertation. Massachusetts Institute of Technology, 1992.

- «Calculating metrical structure», in Cairns, Charles and Raimy, Eric (eds.). Contemporary Views on Architecture and Representations in Phonological Theory. Cambridge: MIT Press, 2009, pp. 191-211.

JAKOBSON, Roman and John Lotz: «Axioms of a versification system: exemplified by the Mordvinian folksongs», in Roman Jakobson, Selected Writings, V: On verse, Its Masters and Explorers. The Hague: Mouton, 1979, pp. 160-166.

JAKOBSON, Roman: «Slavic epic verse», in Roman Jakobson, Selected Writings, IV: Slavic Epic Studies. The Hague: Mouton, 1979, pp. 414-463.

KIPARSKY, Paul: «Metrics and Morphophonemics in the Kalevala», in Charles E. Gribble (ed.). Studies presented to Professor Roman Jakobson by his Students, Cambridge [Massachusetts]: Slavica, 1968, pp.137-148. - «Metrics and Morphophonemics in the Rigveda», in Michael K. Brame (ed.). Contributions to Generative Phonology. Austin: University of Texas Press, 1968, pp. 171-200.

- «Stress, Syntax, and Meter». Language, 51, 1975, pp. 576-616.

LEMOS, Fernando: Fernando Pessoa e a Nova Métrica: a imitação de formas e metros líricos greco-romanos em Ricardo Reis. Edição e estudo de Fernando Lemos. Lisboa: Editorial Inquérito, 1993. 
LEVY, Jiri: «A contribution to the typology of accentual-syllabic versification», in Jiri Levy, Paralipomena. Brno: Purkyne Univ., 1971, pp. 9-21.

LOTZ, John: «Metric Typology», in Thomas Sebeok (ed.), Style in Language. Cambridge, Massachusetts: MIT Press, 1960, pp. 135-148.

MACRÍ, Oreste: Ensayo de métrica sintagmática. Madrid: Editorial Gredos, 1969.

MAGNUSON, Karl and Frank Ryder: «The Study of English Prosody: An Alternative Proposal». Poetics, 12, 1970, pp. 143-154.

McCARTHY, John and Alan Prince: «Generalized Alignment» in Geert Booij and Jap van Marle (eds.). Yearbook of Morphology. Berlin: Kluwer Academic Publishers, 1993, pp. 79-153.

NESPOR, Marina and Irene Vogel: Prosodic Phonology. (With a new foreword). Studies in Generative Grammar, 28. Berlin; New York: Mouton de Gruyter, 2007 [First publication in 1986].

PATRÍCIO, Rita: Episódios da teorização estética em Fernando Pessoa. Tese de Doutoramento em Ciências da Literatura apresentada no Instituto de Letras e Ciências Humanas da Universidade do Minho. Área de Especialização em Teoria da Literatura, 2008. [Policopied Text].

PESSOA, Fernando: Escritos sobre Génio e Loucura. Edição de Jerónimo Pizarro. Edição Crítica de Fernando Pessoa, Série Maior, Volume VII, 2 tomos. Lisboa: Imprensa Nacional-Casa da Moeda, 2006.

-Eu Sou Uma Antologia: 136 autores fictícios. Edição de Jerónimo Pizarro e Patricio Ferrari. Lisboa: Tinta-da-China, 2013.

PIERA, Carlos: Spanish Verse and the Theory of Meter. Dissertation presented at UCLA, 1980 [Unpublished].

— «Rephrasing Line-End Restrictions», in Jean-Louis Aroui and Andy Arleo (eds). Toward a Typology of Poetic Forms. Amsterdam: John Benjamins, 2009, pp. 287-303.

PIZARRO, Jerónimo: Pessoa existe? Lisboa: Ática, 2012.

PIZARRO, Jerónimo, Patricio Ferrari and Antonio Cardiello: A Biblioteca Particular de Fernando Pessoa. Acervo Casa Fernando Pessoa [Fernando Pessoa House], 3 vols. Bilingual Edition. Lisboa: D. Quixote, vol I, 2010.

PRINCE, Alan: «Metrical Forms», in Paul Kiparsky and Gilbert Youmans (eds.), Phonetics and Phonology: Rhythm and Meter. San Diego: Academic Press. 1989, pp. 45-80.

PRINCE, Alan and Paul Smolensky: Optimality Theory: Constraint Interaction in Generative Grammar. Rutgers University Center for Cognitive Science and Computer Science Department, University of Colorado at Boulder. Oxford: Blackwell, 1993.

RIAD, Tomas: «Review of Fabb and Halle 2008». Phonology, 27, 3, 2010, pp. 542-551.

SEVERINO, Alexandrino Eusébio: Fernando Pessoa na África do Sul. Lisboa: D. Quixote, 1983. [Originally published in two vols., Marília [Brasil]: Fac. de Filosofía, Ciências e Letras, 1969-1970]. 
SPAGGIARI, Barbara: «The decasyllable in Portugal», in Christine Michaux and Marc Dominicy, (eds.). Linguistic Approaches to Poetry. Belgian Journal of Linguistics, 15, Special Issue, 2003, pp. 173-186.

TSUR, Reuven: Poetic Rhythm: Structure and Performance. An Empirical Study in Cognitive Poetics. Bern: Lang, 1998.

YOUNG, Francis Brett: Robert Bridges: A Critical Study. London: Martin Secker, 1914. 